\title{
PENGARUH RETURN ON ASSET (ROA) DAN DEBT TO ASSET RATIO (DAR) TERHADAP HARGA SAHAM PADA PT JAYA REAL PROPERTY, TBK PERIODE TAHUN 2010 - 2019
}

\author{
1Ersa Liani, ${ }^{2 *}$ Adji Widodo \\ Universitas Pamulang, Tangerang Selatan, Banten, Indonesia \\ *dosen01554@unpam.ac.id
}

\begin{abstract}
Abstrak
Penelitian ini bertujuan untuk menjelaskan pengaruh Return On Asset (ROA) sebagai variabel bebas (X1), dan Debt to Asset Ratio (DAR) sebagai variabel bebas (X2) terhadap Harga Saham sebagai variabel terikat (Y). Populasi dalam penelitian ini adalah seluruh Laporan Keuangan PT JayaReal Property Tbk dan sampel yang digunakan adalah Laporan Neraca dan Laporan Laba Rugi pada periode tahun 2010 sampai dengan 2019. Jenis penelitian ini menggunakan metode pengujian hipotesis, dengan teknik statistik yang bersifat kuantitatif deskriptif. Alat analisis yang digunakan adalah regresi linear berganda menggunakan program Statistical Package for the Social Sciences version 25 (SPSS25). Berdasarkan hasil uji $\mathrm{t}$ (parsial ) menunjukkan bahwa Return On Asset berpengaruh signifikan terhadap Harga Saham, sedangkan pada variabel Debt to Asset Ratio tidak terdapat pengaruh dan tidak signfikan terhadap Harga Saham. Berdasarkan hasil uji f (secara simultan) menunjukkan bahwa terdapat pengaruh yang signifikan antara variabel Return On Assetdan Debt to Asset Ratio terhadap Harga Saham.
\end{abstract}

Kata Kunci: Return On Asset, Debt To Asset Ratio, Harga Saham

\begin{abstract}
This study aims to explain the effect of Return On Assets (ROA) as an independent variable (X1), and Debt to Asset Ratio (DAR) as an independent variable (X2) on stock prices as the dependent variable (Y). The population in this study is all the Financial Statements of PT Jaya Real Property Tbk and the sample used is the Balance Sheet and Income Statement for the period 2010 to 2019. This type of research uses a hypothesis testing method, with descriptive quantitative statistical techniques. The analytical tool used is multiple linear regression using the Statistical Package for the Social Sciences version 25 (SPSS25) program. Based on the results of the test (partial) shows that Return on Assets has a significant effect on stock prices, while the Debt to Asset Ratio variable has no effect and is not significant on stock prices. Based on the results of the $f$ test (simultaneously) it shows that there is a significant influence between the Return On Assets and Debt to Asset Ratio variables on stock prices.
\end{abstract}

Keywords: Return On Asset, Debt to Asset Ratio, Stock Price

\section{PENDAHULUAN}

Pada era industri 4.0 saat ini, dimana industri 4.0 adalah sebuah era industri digital, dimana seluruh bagian yang ada didalamnya saling berkolaborasi dan berkomunikasi secara real time dimana saja kapan saja dengan pemanfaatan IT (teknologi informasi) berupa internet dan pada era ini persaingan di dunia bisnis semakin ketat. Hal ini ditandai dengan semakin banyaknya perusahaan property dan real estate yang masuk pasar modal. Maka investor harus pintar memilih perusahaan yang mana yang terakhir ini terus meningkat, diperlukan ketelitian dan kecermatan dalam menentukan pilihan atas perusahaan property mana yang akan dipilih untuk dijadikan tempat berinvestasi. Perkembangan pasar modal di Indonesia memberikan bukti bahwa pasar modal menjadi alternative investasi bagi masyarakat Indonesia. Menurut Herispon (2018:73) "pasar modal (capital market) adalah tempat bertemunya penawaran dan permintaan dana jangka menengah dan dana jangka panjang".

Bagi para investor, nilai harga saham masih menjadi primadona bagi patokan untuk mereka menentukan nilai investasi yang akan mereka ambil. Menurut Wijaya (2017:98) "saham dapatdidefinisikan sebagai tanda penyertaan atau kepemilikan seseorang atau badan didalam perusahaan". Menurut Kasmir (2017:66) "laporan keuangan yaitu laporan yang menunjukkan kondisi keuangan perusahaan pada saat ini (kondisi keuangan terkini) atau dalam suatu 
periode tertentu. Kondisi perusahaan terkini merupakan keadaan keuangan perusahaan pada tanggal tertentu (untuk neraca) dan periode tertentu (untuk laporan laba rugi)".

PT. Jaya Real Property adalah sebuah perusahaan yang bergerak di bidang Property dan Real Estate. PT. Jaya Real Property didirikan pada tahun 1979 dengan alamat kantor pusat di CBD Emerald Blok CE/A No. 1 Jl. Boulevard Bintaro Jaya Tangerang, Banten.

Berdasarkan latar belakang penelitian diatas, penulis memilih untuk melakukan penelitian denganjudul penelitian "Pengaruh Return On Asset (ROA) Dan Debt To Asset Ratio (DAR) terhadap Harga Saham pada PT. Jaya Real Property, Tbk periode 2010 - 2019“.

\section{Return On Asset (ROA)}

Menurut Sutrisno (2017:213) "Return On Asset (ROA) juga sering disebut sebagai rentabilitas ekonomic merupakan ukuran kemampuan perusahaan dalam menghasilkan laba dengan semua aktivayang dimiliki oleh perusahaan". Berdasarkan pengertian tersebut dapat disimpulkan bahwa Return On Asset (ROA) merupakan rasio yang digunakan untuk mengukur kemampuan perusahaan dalam menghasilkan laba atas kontribusi asset perusahaan. Semakin tinggi nilai ROA maka semakin baik pula kinerja perusahaan dalam menghasilkan laba.

Berikut adalah rumus dari ROA:

Return On Asset (ROA) = Laba Bersih x 100\% Total Aset

\section{Debt To Asset Ratio (DAR)}

Menurut Kasmir (2012:156) "Debt to Asset Ratio (DAR) merupakan rasio utang yang digunakan untuk mengukur perbandingan antara total utang dengan total aktiva. Rata-rata industri Debt to Asset Ratio adalah 35\%." Berdasarkan pengertian di atas dapat disimpulkan bahwa Debt to Asset Ratio (DAR) merupakan rasio yang digunakan untuk mengukur kemampuan perusahaan dalam mengelola asset yang dibiayai dengan utang atau seberapa besarutang perusahaan berpengaruh terhadap pembiayaan asset.

Berikut adalah rumus dari DAR:

Debt to Asset Ratio (DAR) = Total Liabilitas $\mathrm{x}$ $100 \%$

Total Aset

Tabel 1. Standar Industri Rasio Solvabilitas

\begin{tabular}{|c|c|c|c|c|}
\hline $\begin{array}{c}\text { N } \\
\text { o }\end{array}$ & $\begin{array}{c}\text { Jenis } \\
\text { Rasio }\end{array}$ & $\begin{array}{c}\text { Standar } \\
\text { Industri }\end{array}$ & \multicolumn{2}{|c|}{ Interprestasi } \\
\hline \multirow{2}{*}{1} & \multirow{2}{*}{ DAR } & \multirow{2}{*}{$35 \%$} & $\begin{array}{c}<30 \\
\%\end{array}$ & Sehat \\
\cline { 4 - 5 } & & $\begin{array}{c}>35 \\
\%\end{array}$ & $\begin{array}{c}\text { Kurang } \\
\text { Sehat }\end{array}$ \\
\hline \multirow{2}{*}{2} & \multirow{2}{*}{ DER } & \multirow{2}{*}{$80 \%$} & $\begin{array}{c}<80 \\
\%\end{array}$ & Sehat \\
\cline { 4 - 5 } & & $\begin{array}{c}>80 \\
\%\end{array}$ & $\begin{array}{c}\text { Kurang } \\
\text { Sehat }\end{array}$ \\
\hline
\end{tabular}

\section{Harga Saham}

Menurut Halim (2015:84) "harga saham adalah suatu nilai yang dibayar oleh investor pada saat sekarang. Harga saham merupakan nilai sekarang (present values) dari penghasilan-penghasilan yang akan diterima oleh pemodal pada masa yang akan datang. Untuk menghitung nilai sekarang tersebut digunakan tingkat keuntungan yang dianggap layak".

Harga pasar saham juga menunjukan nilai dari perusahaan itu sendiri. Semakin tinggi nilai dari harga pasar saham suatu perusahaan, maka investor akan tertarik untuk menjual sahamnya. Bursa saham merupakan salah satu indikator perekonomian suatu negara maka diperlukan suatu pertimbangan tentang transaksi yang terjadi dalam bursa sepanjang periode tertentu. Perhitungan ini akan digunakan sebagai tolak ukur kondisi perekonomian suatu negara.

Berdasarkan pengertian di atas dapat disimpulkan bahwa harga saham adalah harga saham adalah harga yang dibentuk dari interaksi penjual dan pembeli saham yang dilatarbelakangi oleh harapan mereka terhadap profit (keuntungan) perusahaan. 


\section{Kerangka Berpikir}

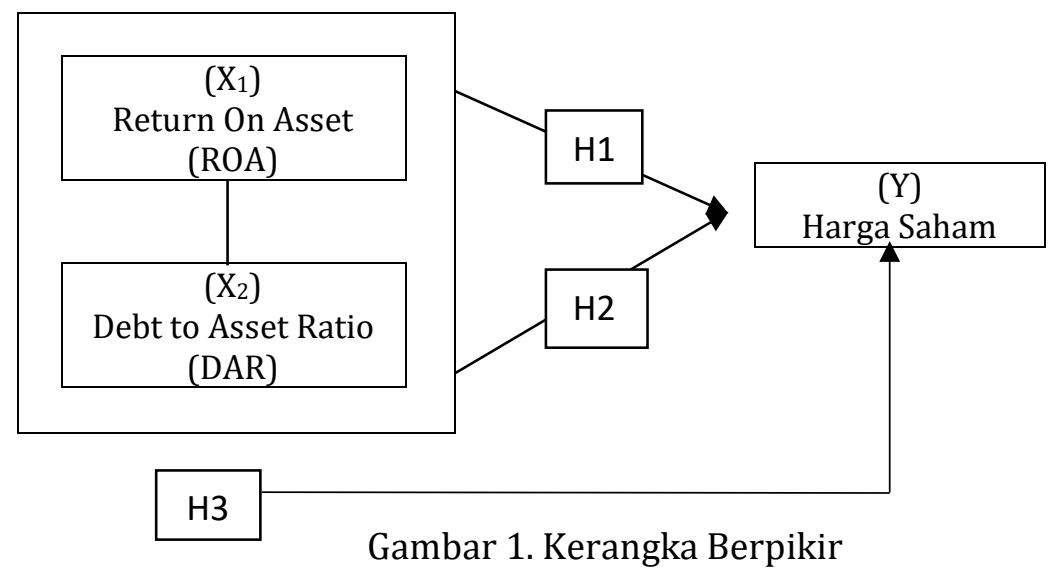

\section{Hipotesis}

Ha1 $\neq 0$, Terdapat pengaruh Return On Asset (ROA) terhadap Harga Saham pada PT Jaya Real Property, Tbk tahun 2010-2019.

Ho1 = 0, Tidak terdapat pengaruh Return On Asset (ROA) terhadap Harga saham pada PT Jaya Real Property, Tbk tahun 2010-2019.

Ha2 $\neq 0$, Terdapat pengaruh Debt to Asset Ratio (DAR) terhadap Harga Saham pada PT Jaya Real Property, Tbk tahun 2010-2019.

$\mathrm{Ho} 2=0$, Tidak terdapat pengaruh Debt to Asset Ratio (DAR) terhadap Harga Saham pada PT JayaReal Property, Tbk tahun 2010-2019.

Ha3 $\neq 0$, Terdapat pengaruh Return On Asset (ROA) dan Debt to Asset Ratio (DAR) secara bersama sama Harga Saham pada PT Jaya Real Property, Tbk tahun 20102019.

Ho3 = 0, Tidak terdapat pengaruh Return On Asset (ROA) dan Debt to Asset Ratio (DAR) secara bersama-sama terhadap Harga Saham pada PT Jaya Real Property, Tbk tahun 2010-2019.

\section{METODE}

\section{Jenis Penelitian}

Pada penelitian ini penulis menggunakan jenis penelitian kuantitatif. Dimana penelitian ini menggunakan datadata laporan keuangan PT. Jaya Real Properti Tbk periode 2010- 2019.

Menurut Sugiyono (2018:23) "metode kuantitatif dapat diartikan sebagai metode penelitian yang berlandaskan pada filsafat positivisme, digunakan untuk meneliti pada populasi atau sampel tertentu, pengumpulan data menggunakan instrument penelitian, analisis data bersifat kuantitatif/statistik, dengan tujuan untuk menggambarkan dan menguji hipotesis yang telah ditetapkan".

\section{Tempat dan Waktu Penelitian}

Tempat penelitian ini dilakukan pada PT. Jaya Real Property Tbk, yang bergerak dibidang yang bergerak di bidang Property dan Real Estate yang beralamat di kantor pusat di CBD Emerald Blok CE/A No. 1 Jl. Boulevard Bintaro Jaya Tangerang, Banten. Adapun data-data penelitian diperoleh dari kantor perwakilan Bursa Efek Indonesia dengan menggunakan akses internet ke website resmi perusahaan. Penelitian dilakukan untuk memproleh data di mulai selama (sembilan) bulan, mulai tanggal November 2020 sampai dengan juli 2021.

\section{Populasi dan Sampel}

Menurut Sugiyono (2016:80) "populasi adalah wilayah generalisasi yang terdiri dari atas objek atau subjek yang mempunyai kualitas dan karakteristik tertentu yang ditetapkan oleh peneliti untuk dipelajari dan kemudian ditarik kesimpulannya". Populasi bukan hanya sekedar jumlah yang ada pada objek atau subjek yang dipelajari, tetapi meliputi seluruh karakteristik atau sifat yang dimiliki oleh objek atau subjek tersebut. Populasi dalam penelitian ini adalah seluruh laporan keuangan yang berupa laporan neraca dan 
laporan laba rugi PT. Jaya Real Property, Tbk yang terdapat di www.idx.com.

$$
\text { Menurut Sugiyono (2016:81) }
$$

"sampel adalah bagian dari jumlah dan karakteristik yang dimiliki oleh populasi tersebut". Adapun sampel yang diambil dalam penelitian ini adalah berupa laporan keuangan neraca dan laporan laba rugi PT. Jaya Real Property, Tbk periode tahun 2010 sampai dengan tahun 2019.

\section{Teknik Pengumpulan Data}

Untuk mendapatkan data yang menunjuang dalam penelitian ini, maka penulis melakukan pengumpulan data dengan beberapa cara sebaga berikut:

1. Penelitian Perpustakaan

Penelitian kepustakaan yaitu dengan cara mengumpulkan data melalui beberapa teori yaitu dari bukubuku, laporan keuangan, jurnal-jurnal ilmiah yang berkaitan dengan masalah yang diteliti.

2. Dokumentasi

Dokumentasi yaitu dilakukan untuk memperoleh data yang berhubungan dengan sejarah berdirinya perusahaan, struktur organisasi perusahaan, dan laporan keuangan PT. Jaya Real Property, Tbk periode tahun 2010 sampai dengan tahun 2019.

\section{HASIL DAN PEMBAHASAN \\ Hasil Penelitian \\ Uji Normalitas Data}

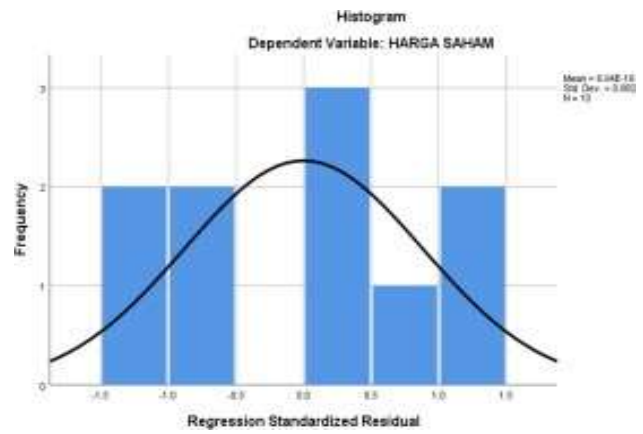

Gambar 2. Hasil Uji Normalitas Menggunakan Histogram

Sumber: Hasil Pengolahan Data

Output Menggunakan SPSS Versi 25

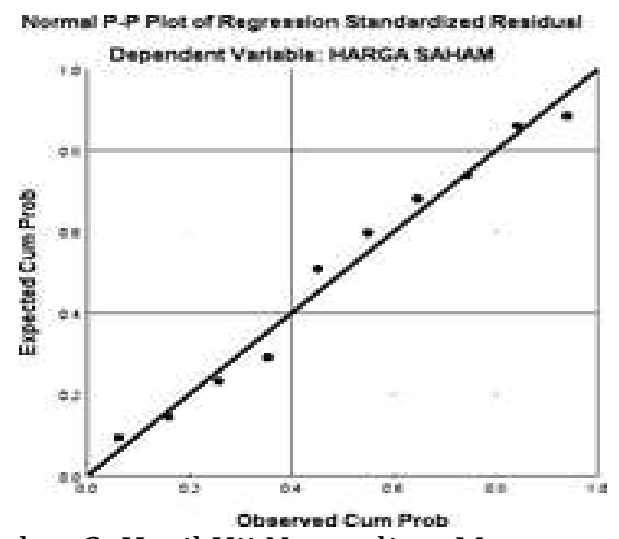

Gambar 3. Hasil Uji Normalitas Menggunakan Grafik P-Plot

Sumber: Hasil Pengolahan Data Output Menggunakan SPSS Versi 25

Tabel 1. Hasil Uji Kolmogorov-Smirnov OneSample Kolmogorov-Smirnov Test Unstandardized Residual

\begin{tabular}{llr}
\hline $\mathrm{N}$ & & 10 \\
Normal & Mean & .0000000 \\
\cline { 2 - 3 } Parameters ${ }^{\mathrm{a}, \mathrm{b}}$ & Std. Deviation & 139.37392404 \\
Most Extreme & Absolute & .133 \\
\cline { 2 - 3 } & & .133 \\
\cline { 2 - 3 } & Positferences & -.110 \\
\cline { 2 - 3 } & Negative & .133 \\
\hline Test Statistic & & $.2000^{\mathrm{c}, \mathrm{d}}$ \\
\hline Asymp. Sig. (2-tailed) & di & atas
\end{tabular}
menunjukkan bahwa Hasil Uji KolmogorovSmirnov mempunyai nilai signifikan 0,200. Hal ini menunjukkan 0,200>0,05 maka dapat disimpulkan bahwa data residual yang digunakan dalam penelitian ini terdistribusi normal.

\section{Uji Autokorelasi}

Tabel 2. Hasil Uji Autokorelasi Model Summary

R Adjusted Std.

Model RSquare R Error of DurbinSquare the Watson Estimate

\begin{tabular}{lllll}
\hline 1 & $.7966^{\mathrm{a}} .634$ & .529158 .035 & 1.158 \\
\hline
\end{tabular}

Sumber: Hasil Pengolahan Data Output Menggunakan SPSS Versi 25

Dengan demikian nilai $\mathrm{dL}<\mathrm{d}<\mathrm{dU}$ yaitu $0,0523<1,158<1,6413$, maka dapat disimpulkan bahwa hasilnya tidak dapat disimpulkan. 
Uji Multikolonieritas

Tabel 3. Hasil Uji Multikolinearitas Coefficients ${ }^{\mathbf{a}}$

Collinearity Statistics

\begin{tabular}{lrrr}
\hline 1 & ROA & .746 & 1.340 \\
\cline { 2 - 4 } & DAR & .746 & 1.340 \\
\hline
\end{tabular}

Sumber: Hasil Pengolahan Data Output Menggunakan SPSS Versi 25

Berdasarkan tabel di atas menunjukkan bahwa nilai tolerance untuk masing-masing variabel Independen ROA dan DAR sebesar 0,746 lebih dari $0,1(0,746>0,1)$ dan nilai VIF (Variance Inflation Factor) untuk variabel independen ROA dan DAR yaitu sebesar 1,340 kurang dari $10(1,340<10)$. Maka dapat disimpulkan dalam penelitian ini tidak terjadi masalah multikolinearitas.

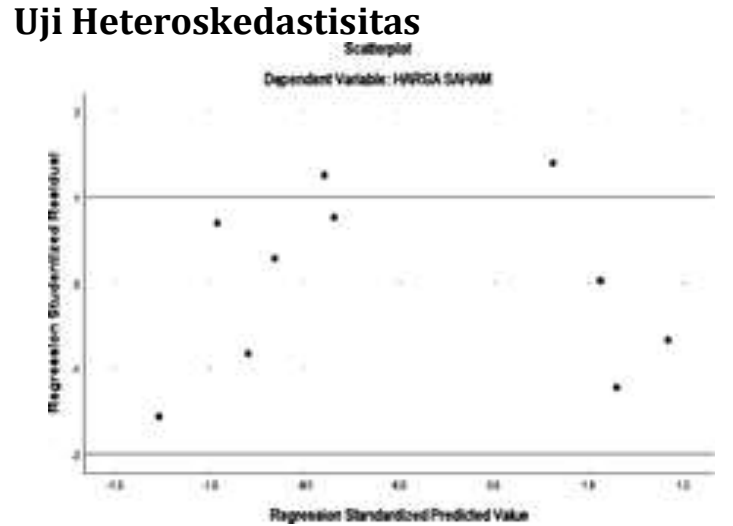

Sumber: Hasil Pengolahan Data Output Menggunakan SPSS Versi 25

Gambar 4. Hasil Uji Heteroskedastisitas

Berdasarkan gambar pada hasil uji heteroskedastisitas menunjukkan bahwa terlihat pada grafik Scatterplot titik-titik menyebar secara acak, tidak membentuk suatu pola tertentu yang jelas baik di atas maupun di bawah angka 0 pada sumbu Y. Hal ini dapat disimpulkan bahwa tidak terjadi heteroskedastisitas pada model regresi.

\section{Analisis Regresi Linear Berganda}

Tabel 4. Hasil Uji Regresi Linier Berganda pada SPSS

\begin{tabular}{|c|c|c|c|c|c|}
\hline \multirow[b]{3}{*}{ Model } & \multicolumn{3}{|c|}{ Coefficients $^{\mathrm{a}}$} & \multirow[b]{3}{*}{$\mathrm{T}$} & \multirow[b]{3}{*}{ Sig. } \\
\hline & $\begin{array}{l}\text { Unstandardized } \\
\text { Coefficients }\end{array}$ & & $\begin{array}{l}\text { Standardized } \\
\text { Coefficients }\end{array}$ & & \\
\hline & B & Std. Error & Beta & & \\
\hline (Constant) & -999.533 & 643.735 & & -1.553 & 3.164 \\
\hline ROA & 138.661 & 41.068 & .895 & 3.376 & .012 \\
\hline DAR & 7.087 & 7.170 & .262 & .988 & .356 \\
\hline
\end{tabular}

Sumber: Hasil Pengolahan Data Output Menggunakan SPSS Versi 25

Berdasarkan tabel Persamaan Regresi Linier Berganda adalah sebagai berikut: $\mathrm{Y}=$ $999,533+138,661 \mathrm{X} 1+7,087 \mathrm{X} 2$

Persamaan regresi di atas mempunyai arti sebagai berikut:

a. Koefisien Konstanta (a) Sebesar - 999,533

Berarti jika ROA dan DAR bernilai 0

(Nol) maka nilai variabel dependen Harga Saham sebesar - 999,533

b. Variabel Return On Asset (X1) Sebesar 138,661

Mempunyai Koefisien regresi dengan arah positif sebesar sebesar 138,661. Hal ini menunjukkan bahwa kenaikan $1 \%$ dari variabel ROA maka akan meningkatkan Harga Saham sebesar 138,661 dan menunjukkan bahwa ROA berpengaruh positif terhadap Harga Saham.

c. Variabel Debt To Asset Ratio (X2) Sebesar 7,087
Mempunyai koefisien regresi dengan arah positif sebesar 7,087 Hal ini menunjukkan bahwa setiap kenaikan $1 \%$ dari rasio hutang dengan aktiva (DAR) akan mendorong peningkatan Harga Saham sebesar 7,087 dengan asumsi variabel yang mempengaruhi Harga Saham tetap. Dan sebaliknya jika DAR mengalami penurunan setiap $1 \%$ maka mengakibatkan penurunansebesar 7,087 dengan asumsi variabel yang mempengaruhi Harga Saham tetap.

\section{Koefisien Determinasi $\left(\mathbf{R}^{\mathbf{2}}\right)$}

Tabel 5. Hasil Uji Koefisien Determinasi ( $\left.\mathrm{R}^{2}\right)$ Model Summary

\begin{tabular}{cc|c|c|c} 
Model R & R Square & $\begin{array}{c}\text { Adjusted R } \\
\text { Square }\end{array}$ & $\begin{array}{c}\text { Std. Error of } \\
\text { the } \\
\text { Estimate }\end{array}$ \\
\hline 1 & $.796^{\mathrm{a}}$ & .633 & .529158 .145 \\
\hline
\end{tabular}


Sumber: Hasil Pengolahan Data

Output Menggunakan SPSS Versi 25

Berdasarkan tabel diperoleh Koefisien Determinasi $\mathrm{R}$ Square $\left(\mathrm{R}^{2}\right)$ sebesar 0,633. Maka (KD $=\mathrm{r}^{2} \times 100 \%=0,633 \times 100 \%=$ $63,3 \%$ jadi dapat disimpulkan bahwa Return
On Asset (ROA) dan Debt to Asset Ratio (DAR) berpengaruh terhadap Harga Saham sebesar $63,3 \%$ sedangkan sisanya sebesar $36,7 \%$ dipengaruhi oleh faktor lain yang tidak diteliti dalam penelitian ini

Uji T

Tabel 6. Hasil Uji T (Uji secara Parsial)

Coefficients $^{\mathrm{a}}$

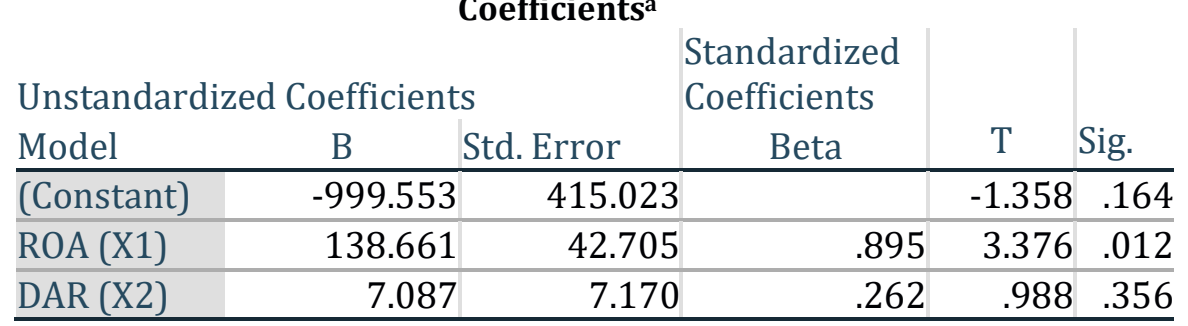

Sumber: Hasil Pengolahan Data Output Menggunakan SPSS Versi 25

Berdasarkan tabel uji $\mathrm{t}$ diatas dapat diketahui perhitungan uji $\mathrm{T}$ dari masingmasing variabel yaitu sebagai berikut:

Nilai thitung dari variabel Return On Asset sebesar 3,376 lebih besar dari nilai ttabel sebesar 2,364 $(3,376>2,364)$ dengan nilai signifikan 0,012 lebih kecil dari 0,05 $(0,012<0,05)$ sehingga Ha1 diterima yang artinya berpengaruh signifikan terhadap harga saham dan Ho1 ditolak. Dengan demikian dapat disimpulkan bahwa secara parsial Return On Asset (ROA)berpengaruh signifikan terhadap Harga Saham. Nilai thitung dari variabel Debt to Asset Ratio sebesar 0,988 lebih kecil dari ttabel sebesar $2,364(0,988<2,364)$ dengan nilai signifikan 0,356 lebih besar dari $0,05(0,356>0,05)$ sehinggaHa2 ditolak dan $\mathrm{Ho} 2$ diterima yang artinya secara parsial tidak berpengaruh dan tidak signifikan terhadap harga saham. Dengan demikian dapat disimpulkan bahwa secara parsialDebt to Asset Ratio (DAR) tidak berpengaruh dan tidak signifikan terhadap Harga Saham.

Uji F

Tabel 7. Hasil Uji F (Uji secara Simultan) ANOVA $^{\text {a }}$

\begin{tabular}{|c|c|c|c|}
\hline Model & $\begin{array}{l}\text { Sum of } \\
\text { Squares }\end{array}$ & Df & $\begin{array}{r}\text { Mean } \\
\text { Square }\end{array}$ \\
\hline
\end{tabular}

Regression302341.729 2151170.9656.044.030

\begin{tabular}{llll}
\hline Residual & 175068.271 & 7 & 25009.753
\end{tabular}

\begin{tabular}{lll|l|l|l|}
\hline Total & 477410.0009 & \\
\hline
\end{tabular}

Sumber: Hasil Pengolahan Data Output Menggunakan SPSS Versi 25
Berdasarkan tabel menunjukkan bahwa nilai Fhitng diperoleh sebesar 6,044 > nilai Ftabel yaitu 4,740 dengan nilai tingkat signifikan sebesar 0,030<0,05, maka dapat diartikan bahwa Ha3 diterima artinya Return On Asset (ROA) dan Debt to Asset Ratio (DAR) secara simultan berpengaruh signifikan terhadap Harga Saham dan Ho3 ditolak. Dengan demikian dapat disimpulkan bahwa secara simultan Return On Asset (ROA) dan Debt to Asset Ratio (DAR) berpengaruh signifikan terhadap Harga Saham.

\section{SIMPULAN}

Berdasarkan hasil penelitian dan pembahasan yang telah diuraikan sebelumnya mengenai pengaruh Return On Asset (ROA) dan Debt to Asset Ratio (DAR) terhadap Harga Saham pada PT. Jaya Real Property Tbk, maka dapat ditarik kesimpulan sebagai berikut:

1. Return On Asset (ROA) pada PT. Jaya Real Property Tbk terhadap harga saham periode 2010- 2019, secara parsial berpengaruh signifikan terhadap Harga Saham. Artinya, total aktiva yang dipergunakan untuk beroperasi perusahaan mampu memberikan laba bagi perusahaan. Jadi jika suatu perusahaan Return On Asset (ROA) tinggi maka semakin baik, karena tingkat keuntungan yang dihasilkan perusahaan dari pengelolaan assetnya semakin besar, dengan pengelolaan assetyang semakin besar dan efisien maka tingkat kepercayaan investor terhadap 
perusahaan akan meningkat yang nantinya akan meningkatkan harga saham.

2. Debt to Asset Ratio (DAR) pada PT. Jaya Real Property Tbk terhadap harga saham periode 2010 - 2019 secara parsial tidak berpengaruh dan tidak signifikan terhadap Harga Saham. Artinya semakin tinggi Debt to Asset Ratio (DAR) suatu perusahaan, maka semakin besar resiko yang dihadapi, daninvestor akan meminta tingkat keuntungan yang semakin tinggi, resiko yang tinggi menunjukkanproporsi modal sendiri yang rendah untuk membiayai aktiva. Hal ini akan direspon negatif olehpara investor dipasar modal.

3. Return On Asset (ROA) dan Debt to Asset Ratio (DAR) pada PT. Jaya Real Property Tbk terhadap harga saham periode 20102019 dapat disimpulkan bahwa secara simultan Return On Asset (ROA) dan Debt to Asset Ratio (DAR) berpengaruh signifikan terhadap Harga Saham. Artinya secara bersama-sama Return On Asset (ROA) dan Debt to Asset Ratio (DAR) mempunyai pengaruh terhadap harga saham.

\section{DAFTAR PUSTAKA}

Christine, C. (2017). PENGARUH RETURN ON ASSETS (ROA), EARNING PER SHARE (EPS), DAN NET PROFIT MARGIN (NPM) TERHADAP HARGA SAHAM PT BUMI SERPONG DAMAI, Tbk. DAN ENTITAS ANAK. FIN-ACC (Finance Accounting), 1(12).

Halim, A. (2015). Auditing Dasar-Dasar Audit Laporan Keuangan Edisi Kelima. Yogyakarta: Unit Penerbit dan Percetakan STIM YKPN.

Haque, M. G., et al. (2021). Micro Financial Sharia Non-bank Strategic Analysis: a Study at BMT Beringharjo, Yogyakarta. Budapest International Research and Critics Institute (BIRCI-Journal): Humanities and Social Sciences, 4(2), 1677-1686.

Hendri, E. (2019). Pengaruh Debtto Asset Ratio (Dar), Long Term Debt To Equity Ratio (Ltder) Dan Net Profit Margin (Npm) Terhadap Harga Saham Pada Perusahan Perbankan Yang Terdaftar Di Bursa Efek Indonesia. Jurnal Media Wahana Ekonomika, 12(2).
Herispon. (2018). Buku Ajar Manajemen Keuangan (Financial Management) Edisi Revisi Sekolah Tinggi Ilmu Ekonomi. Riau

Iqmal, FM., Putra, IGS., (2020). Macroeconomic factors and influence on stock return that impact the corporate values. International Journal of Finance \& Banking Studies, 9 (2), (2147-4486).

Kasmir. (2012). Analisis Laporan Keuangan. Edisi 5. Jakarta: PT. Rajagrafindo Persada.

Lutfi, A. M., et al. (2021). Pengaruh Capital Adequacy Ratio Dan Bopo Ratio Terhadap Return On Asset Pada Pt. Bank Muamalat Indonesia, Tbk Periode 2010-2019. Jurnal

Ekonomi Efektif, 3(3), 420-428.

Murti, R. A., \& Kharisma, F. (2020). Pengaruh Debt To Equity Ratio dan Debt To Asset Ratio Terhadap Harga Saham pada Perusahaan Consumer Goods yang Tercatat di BEI Periode Tahun 20132017. Borneo Student Research (BSR), 1(2), 1155-1163.

Noryani, Y. B. G., et al. (2020). Did ISO 45001, ISO 22000, ISO 14001 and ISO 9001 Influence Financial Performance? Evidence from Indonesian Industries. PalArch's Journal of Archaeology of Egypt/Egyptology, 17(7), 6930-6950.

Pujiati, H., et al. (2021). Effect of ISO 9001: 2015 Quality Management Implementation in Education on School Performance. Journal of Contemporary Issues in Business and Government, 27(1), 1848-1855.

Putra, IGS., Sunarsi, D., (2020). Comparison of Financial Performance in Banking with High Car and Low Car (Study of Banks Approved in The Kompas 100 Index for The Period 2013-2017). International Journal of Psychosocial Rehabilitation, Vol. 24, Issue 02

Santosa, Y. (2018). Pengaruh Return On Assets (ROA) dan Total Assets Turnover (TATO) terhadap Harga Saham pada PT. Ultrajaya Milk, Tbk.

Sitompul, H. P. (2019). Pengaru h Debt to Total Assets Ratio (DAR), Debt to Equity Ratio (DER), dan Earning Per Share (EPS) Terhadap Harga Saham Pada Perusahaan Sub Sektor 
Advertising, Printing, dan Media Yang Terdaftar Di Bursa Efek Indonesia Periode 2013-2016. JOURNAL OF BUSINESS STUDIES, 4(2).

Sugiyono. (2016). Metode Penelitian Kuantitatif Kualitatif \& RND . Bandung: Alfabeta.

Supriyadi, S. G., \& Sunarmi, S. (2018). Pengaruh Current Ratio (Cr), Debt To Assets Ratio (Dar), Earning Per Share (EPS), Dividen Payout Ratio (DPR) Terhadap Harga Saham Pada Perusahaan Manufaktur Sektor Barang Konsumsi Yang Terdaftar Di Bursa Efek Indonesia Periode 2010-2014. Jurnal Education and Economics, 1(4), 450463.

Surahman, Y. (2018). Pengaruh Return On Assets (ROA) dan Earning Per Share (EPS) Terhadap HargaSaham PT. Astra Internasional Tbk. Periode 2009-2016.
Sutrisno. (2017). Manajemen Keuangan Teori, Konsep dan Aplikasi Edisi Kedua. Yogyakarta: EKONISIA.

Suwandi. (2019). Pengaruh Return On Assets (ROA), Return On Equity (ROE) dan Earning Per Share Terhadap Harga Saham PT. Agung Podomoro Land Tbk Tahun 2008-2017.

Widjiarti, K. U., \& Anggraeni, R. D. Pengaruh Debt To Asset Ratio (Dar), Total Asset Turnover (Tato), Return On Asset (Roa), Dan Earning Per Share (Eps) Terhadap Harga Saham Pada Perusahaan Indeks Lq 45 Yang Terdaftar Di Bursa Efek Indonesia Tahun 2013-2017.

Wijaya, D. (2017). Manajemen Keuangan Konsep dan Penerapannya. Jakarta: PT. Grasindo.

www.finance.yahoo.com

www.idnfinancial.com

www.idx.co.id

www.jayaproperty.com 